\title{
Study of Natural Bitumen of Nagornoye Deposit, Troitskneft JSC (the Republic of Tatarstan, Russian Federation) aimed at Processing Options Determination
}

\author{
Alim Feizrakhmanovich Kemalov ${ }^{1}$, Ruslan Alimovich Kemalov ${ }^{1}$, Ilmira Maratovna Abdrafikova ${ }^{1} \&$ Vasil \\ Ilyasovich Gainullin ${ }^{1}$ \\ ${ }^{1}$ Kazan (Volga region) Federal University, Kazan, Russian Federation \\ Correspondence: Kemalov Ruslan Alimovich, Kazan (Volga region) Federal University, 8, Kremlyovskaya \\ street, 420008 Kazan, Russian Federation. E-mail: Kemalov@mail.ru
}

Received: October 15, 2014 Accepted: October 21, 2014 Online Published: December 30, 2014

doi:10.5539/ass.v11n3p296 URL: http://dx.doi.org/10.5539/ass.v11n3p296

\begin{abstract}
The cost of natural bitumen production at present is very high and 3-5 times exceeds the cost of conventional oils production; the technology developers are facing the challenge of developing processes which allow producing high sale price products at a low cost. The present study was aimed at finding out the composition and properties of natural bitumen from Nagornoye deposit of the Republic of Tatarstan (JSC Troitskneft) to determine the possible ways for its processing as well as to definite the processing options. A conclusion made, that the production of residual bitumen of the high-viscosity oils and natural bitumen of Tatarstan Republic (as well as any other region having raw materials with similar composition) will contribute to increase in their production volume and quality by means of compounding of residual and air-blown bitumen, as in this particular case their advantages are combined. In addition, this will contribute to solution of the problem related to introduction of water-bitumen emulsions and bitumen-polymer binders into the road construction of Tatarstan Republic. The use of natural bitumen for production of various commercial bitumen marks and various bitumen products, makes its recovery economically feasible as its conventional recovery and transportation is noncompetitive against conventional oils. At the same time, profitability of a pure bitumen option can be increased by means of a bitumen-fuel option, provided that the diesel fraction is brought in full compliance with the GOST for $\mathrm{S}$ (summer), W (winter) and A (arctic) marks of diesel fuel.
\end{abstract}

Keywords: natural bitumen, processing, composition, properties, diesel fuel, asphaltene-resin components, road bitumen, construction bitumen, residue

\section{Introduction}

Since the cost of natural bitumen production at present is very high and 3-5 times exceeds the cost of conventional oils mining, the technology developers are facing the challenge of developing processes which allow producing high sale price products at a low cost. Therefore, studies aimed at in-depth study of structure and properties in order to find possible ways of processing heavy oil is very relevant and promising, especially in view with an increasing proportion of heavy crude in the structure of hydrocarbon reserves development (Lipaev, 2012; Junaid, 2010; Pavel \& Silverman, 2010; Telyashev, 2008; Long et al., 2006, Prado \& De Klerk, 2014).

The most important indicator of oil quality, which determines the processing method, range and performance characteristics of the obtained petroleum products is the chemical composition and its fraction allocation (Altgelt, 1993; Burruss \& Ryder, 2013; Speight, 2014).

Evaluation of high-viscosity oils and natural bitumen along with conventional oils as potential hydrocarbons source (Salama, 2005; Etherington \& McDonald, 2005), requires a thorough study of density, sulfur content, low temperature and viscosity properties and fractional and structural-group composition.

\section{Method}

\subsection{General Properties of the Natural Bitumen}

The present sample of natural bitumen taken from Nagornoye Deposit, Troitskneft JSC (the Republic of Tatarstan), contained $30 \%$ of water and $1.5 \%$ of mechanical impurities. After dehydration and removal of 
mechanical impurities, the sample was studied for general properties and composition. The examination was implemented in accordance with GOST R 51858-2002 (GOST - Russian state standard, GOST R 51858-2002, 2002), developed by the Institute of Energy Resources Transport (IPTER) and All-Russian Scientific Research Institute of Oil Refining JSC (VNIINP).

The density of the products was determined at $20{ }^{\circ} \mathrm{C}$ using a pycnometer. Dynamic viscosity was determined at $25{ }^{\circ} \mathrm{C}, 50{ }^{\circ} \mathrm{C}, 100{ }^{\circ} \mathrm{C}$ using a rotational viscometer "Rheotest". The principle of studying the rheological properties of a rotary viscometer "Rheotest" is as measured by the shearing stress produced in the sample, placed in a narrow gap between the rotating cone and stationary surface. The rotating cone shaft is connected with a spring, which transmits rotation torque from the cone by a potentiometer. Potentiometer readings are proportional to the rotation torque, which is linearly dependent on the shear stress.

Method for determining the group chemical composition of the petroleum products boiling above $300{ }^{\circ} \mathrm{C}$ based on the principles of liquid-adsorption chromatographical separation gaining following groups: oils, benzene resins, alcohol-benzene resins and asphaltenes; and further separation of oils into the fractions enriched in paraffinic-naphthenic, monocyclic, bicyclic, polycyclic aromatic hydrocarbons (Mykhailova et al., 2013). As an adsorbent was used silica gel of a mark ASK (fraction with the size of particles $0.25-0.5 \mathrm{~mm}$ ).

Paraffin content was determined according to standard method (GOST 11851-85, 1986) as well as the determination of sulfur content (GOST 1437-75, 1977).

\subsection{Operational Properties of the Natural Bitumen Fractions}

\subsubsection{Gasoline Fractions}

Acidity was determined according to standard method (GOST 5985-79, 1980). The essence of the method consists in the titration of the acidic compounds of the tested product with an alcohol solution of potassium hydroxide in the presence of a color indicator and the definition of acidity for light oil fraction, expressed in $\mathrm{mg}$ $\mathrm{KOH} / 100 \mathrm{~cm}^{3}$ (mg KOH/100 ml).

The essence of the iodine number determination method consists in the processing of the tested petroleum product with an alcohol solution of iodine, free iodine titrating with sodium thiosulfate and determining the iodine number of grams of iodine adjoining to $100 \mathrm{~g}$ of petroleum product (GOST 2070-82, 1983).

Sulphur content is determined according to GOST 19121-73 by burning the petroleum product in the tube in its pure form with subsequent absorption of the formed sulfur dioxide with sodium carbonate solution and titration with hydrochloric acid.

Octane number was determined according to standard, so-called, research method (GOST 8226-82, 1983). The method consists in comparing the knock resistance of the tested fuel with the knock resistance of the reference fuels, expressed by the octane number. Knock intensity of the tested fuel is achieved by varying the degree of compression.

\subsubsection{Diesel Fractions}

Cetane number is determined by comparing the hypergolicity of the tested fuel in the engine at different compression ratios with hypergolicity of the fuels with known cetane numbers in the test conditions (GOST 3122-67, 1968).

Ignition temperature was determined according to standard method (GOST 4333-87, 1988) in an open crucible.

Determination of pour point is performed according to GOST 20287-91 Petroleum products. Methods of test for flow point and pour point (GOST 20287-91, 1992). The essence of the method consists in preheating the sample of tested petroleum product, followed by cooling it at a predetermined rate to a temperature at which the sample remains stationary. This temperature is taken as the pour point.

Cloud point is determined analogous to pour point (GOST 5066-91 (ISO 3013-74), 1993).

Actual resins content is determined by evaporation of a tested fuel under a stream of steam in the test conditions and is used for conventional evaluation of the propensity of fuel to gumming during its use in the engine (GOST 8489-85, 1986).

\subsubsection{Operational Characteristics of Vacuum Residue and Commercial Marks of Bitumen}

Ductility was found by determining the maximum length, which can be stretched without breaking bitumen bathed in a special form, spreaded at a constant rate at a temperature of $25^{\circ} \mathrm{C}$ (GOST 11505-75, 1977). 
Penetration was determined according to standard methodic (GOST 11501-78, 1980) by measuring the depth to which a penetrometer needle is immersed in a sample of bitumen under a given load, temperature $\left(25^{\circ} \mathrm{C}\right)$, and time and is expressed in units corresponding to tenths of a millimeter $(0.1 \mathrm{~mm})$.

Adhesion according standard (GOST 11508-74, 1975) is ability of viscous bitumen persist on sand or marble surface, precoated by them, upon exposure to water.

Brittle point is determined by cooling and periodic bending of a sample of bitumen and determining the temperature at which cracks or breaks of a sample of bitumen occurs (GOST 11508-74, 1975).

\section{Results}

\subsection{Natural Bitumen Characteristics}

The results of these studies are given in Table 1. Natural bitumen is classified as high-sulfur $(1.81-3.5)$ in terms of sulfur content, as bituminous (more than $895.0 \mathrm{~kg} / \mathrm{m}^{3}$ ) in terms of density and as maltha class (35-60 \% mass) in terms of asphaltene-resin components content ( $43.3 \%$ mass).

With a comparatively high asphaltene-resin components content, natural bitumen has an insignificant paraffin content $(0.35 \%$ mass $)$.

Table 1. The indicators of natural bitumen from Nagornoye Deposit

\begin{tabular}{ll}
\hline Indicators & Values \\
\hline Density, $\mathrm{kg} / \mathrm{m}^{3}$, at $20^{\circ} \mathrm{C}$ & 1020 \\
Dynamic viscosity, $\mathrm{mPa}$, at a temperature: & 1280,0 \\
$25^{\circ} \mathrm{C}$ & 360,0 \\
$50^{\circ} \mathrm{C}$ & 32,0 \\
$100^{\circ} \mathrm{C}$ & \\
Components content, $\%$ mass: & 3,4 \\
Sulphur & 0,35 \\
Paraffin & \\
Group chemical composition, $\%$ mass: & 21,8 \\
asphaltenes & \\
resins, including: & 9,4 \\
benzene & 12,1 \\
alcohol-benzene & \\
Hydrocarbons: & 14,6 \\
Paraffin-naphtene & 42,1 \\
Aromatic, including: & 6,0 \\
monocyclic & 6,5 \\
bicyclic & 29,6 \\
polycyclic & \\
Fractions content, $\%$ mass: & 110 \\
Boiling starting (bs) temperature, ${ }^{\circ} \mathrm{C}$ & 0,9 \\
bs $-180^{\circ} \mathrm{C}$ & 3,2 \\
$180-250{ }^{\circ} \mathrm{C}$ & 9,8 \\
$250-300^{\circ} \mathrm{C}$ & 8,8 \\
$300-350^{\circ} \mathrm{C}$ & 10,8 \\
$350-400{ }^{\circ} \mathrm{C}$ & 7,3 \\
$400-440^{\circ} \mathrm{C}$ & 59,2 \\
higher $440{ }^{\circ} \mathrm{C}$ &
\end{tabular}

As the gasoline fraction is present in an insignificant amount ( 0.9 mass), firstly the diesel fraction was analyzed. Table 1 served the basis for development of a true boiling temperatures curve (fig. 1), according to which the bitumen of Nagornoye Deposit is characterized by an insignificant content of gasoline fraction ( 0.9 mass) and low content of diesel fraction (21.8 \% mass).

The total yield of fractions, boiled away at temperatures above $300{ }^{\circ} \mathrm{C}$, for natural bitumen is $81.06 \%$ mass, while for Devonian oil, according to literature data (Riazi \& Daubert, 1980; Kraus, 2011; Lipaev, 2012), it is $50-55 \%$ in average, and $60-65 \%$ mass for carbon oil. Such high yield of these natural bitumen fractions is 
obtained mainly due to fractions which boil out at temperatures above $400{ }^{\circ} \mathrm{C}(66.46 \%$ mass $)$. Fraction $350-500$ ${ }^{\circ} \mathrm{C}$ is the main raw material for catalytic cracking and when processing the natural bitumen at a catalytic cracking plant it could be possible to process larger amounts of this fraction (Telyashev, 2008; Poveda \& Molina, 2012; Mustafaev et al., 2013).

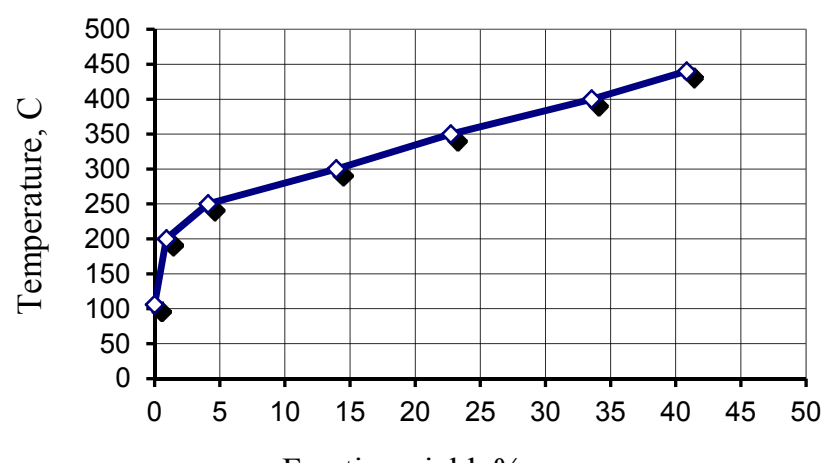

Fraction yield, \% mass

Figure 1. True boiling temperatures curve of natural bitumen

\subsection{Operational Properties of the Natural Bitumen Fractions}

\subsubsection{Gasoline Fractions}

Some gasoline performance indicators are given in Table 2.

Table 2. Gasoline characteristics (bs- $180^{\circ} \mathrm{C}$ fraction)

\begin{tabular}{lll}
\hline Indicators & Values & Commodity product \\
\hline Acidity, $\mathrm{mg} \mathrm{KOH} / 100 \mathrm{ml}$ & & not $>0,8 \div 3,0$ \\
Iodine number, $\mathrm{I}, \Gamma / 100 \Gamma$ & 0,5 & - \\
Sulfur content, $\%$ mass & 1,0 & no $>0,1$ \\
Octane number, $\mathrm{RM}^{*}$ & 52 & $93 \div 95$ \\
\hline
\end{tabular}

$\mathrm{RM}$ - researching method

According to Table 2, gasoline fraction shall undergo deep hydrotreating and catalytic reforming in order to obtain high-octane gasoline. As the gasoline fraction yield bs- $80{ }^{\circ} \mathrm{C}$ is insignificant, its refining shall be done together with diesel fraction followed by fractionation of the gained clean product. At the same time, it is unfeasible to provide production of commercial-grade motor fuel at such a low gasoline fraction content. This fraction can be used as a solvent for domestic needs, without hydrotreating.

Two diesel fuel fractions were analyzed:

- sample no. 1: diesel fractions with strippant temperature up to $300{ }^{\circ} \mathrm{C}$.

- sample no. 2. diesel fractions with strippant temperature up to $350{ }^{\circ} \mathrm{C}$.

\subsubsection{Diesel Fractions}

The main performance indicators of these diesel fractions are given in Table 3:

- Cetane number, which determines high power and economic factors of motor operation; $\left(\mathrm{CN}=\left(v_{20}+17.8\right)\right.$ $\left.1.5879 / \mathrm{d}_{4}{ }^{20}\right)$. This is the main diesel index, it determines motor actuation, rate of pressure increasing, fuel consumption and smoking at the exhaust. The European Diesel Fuel Standard establishes the CN lowest limit at 48 points. In winter, in order to ensure cold motor start, it is recommended to use fuels with CN not less than 45 points (Riazi \& Daubert, 1980; Kraus, 2011).

In other countries, fuel flammability is specified by both a cetane number and diesel index (DI), which is determined with the help of a nomographic chart, when knowing the density at $15{ }^{\circ} \mathrm{C}$ and a final boiling point of a $50 \%$ fraction. Knowing DI, it is possible to calculate $\mathrm{CN}$, there is a certain dependence between them:

$$
\begin{array}{llllllll}
\text { DI } & 20 & 30 & 40 & 50 & 62 & 70 & 80 \\
\text { CN } & 30 & 35 & 40 & 45 & 55 & 60 & 80
\end{array}
$$


- fractional composition, which determines combustion completeness, exhaust smoking and toxicity. In addition, along with the rise of fuel final boiling point, the wear scar diameter and friction coefficient are reduced, which is important for diesel motors, operated at elevated pressures.

- viscosity and density, providing regular fuel supply, pulverization in the combustion chamber and filter system operability;

- low temperature characteristics, which determine feed system functioning at ambient subzero temperatures;

Table 3. Diesel fractions indicators

\begin{tabular}{|c|c|c|c|c|}
\hline \multirow[t]{2}{*}{ Indicators } & \multicolumn{2}{|c|}{ Fractions, ${ }^{\circ} \mathrm{C}$} & \multicolumn{2}{|c|}{$\begin{array}{c}\text { GOST 305-82 } \\
(\text { GOST } 305-82,1983)\end{array}$} \\
\hline & Sample No.1 & Sample No.2 & $\mathrm{S}^{*}$ & $\mathrm{~W}$ \\
\hline Density at $20{ }^{\circ} \mathrm{C}, \mathrm{kg} / \mathrm{m}^{3}$ & 826,0 & 836,0 & no $>860$ & no $>840$ \\
\hline Cetane number & 46 & 47 & no $<45$ & no $<45$ \\
\hline \multicolumn{5}{|l|}{$\begin{array}{c}\text { Fractional composition, } \\
\text { boiling as, }{ }^{\circ} \mathrm{C} \text { : }\end{array}$} \\
\hline $50 \%$ & 265 & 280 & no $>280$ & no $>280$ \\
\hline $96 \%$ & 292 & 340 & no $>360$ & no $>340$ \\
\hline Kinematic viscosity at $20^{\circ} \mathrm{C}, \mathrm{sSt}$ & 3,5 & 5,5 & $3,0-6,0$ & $1,8-5,0$ \\
\hline Ignition temperature (closed crucible), ${ }^{\circ} \mathrm{C}$ & 40,0 & 45,0 & no $<40$ & no $<35$ \\
\hline Pour point, ${ }^{\circ} \mathrm{C}$ & $-24^{\circ} \mathrm{C}$ & $-19^{\circ} \mathrm{C}$ & no $>(-10)$ & no $>-35$ \\
\hline Cloud point, ${ }^{\circ} \mathrm{C}$ & $-12^{\circ} \mathrm{C}$ & $-8{ }^{\circ} \mathrm{C}$ & no $>(-5)$ & no $>-25$ \\
\hline Actual resins content, $\mathrm{mg} / 100 \mathrm{~cm}^{3}$ of fuel & 40 & 30 & no $>40$ & no $>30$ \\
\hline Sulfur content, $\%$ mass & 1,2 & 1,4 & no $>0,2-0,5$ & $\begin{array}{c}\text { no }> \\
0,2-0,5\end{array}$ \\
\hline
\end{tabular}

*S - summer diesel fuel (DF), $\mathrm{W}$ - winter DF

\section{Discussion}

According to Table 3, in terms of content of actual tar both the fractions are at the limit of GOST (GOST 305-82, 1983) requirements; in terms of the pour point, they correspond to GOST requirements for summer fuel. As it was expected, the pour point increases along with increase of the distillates yield: for sample no. $1-t_{\text {strip. }}=(-24$ $\left.{ }^{\circ} \mathrm{C}\right)$; and for sample no. $2-\mathrm{t}_{\text {strip. }}=\left(-19^{\circ} \mathrm{C}\right)$. In terms of all the other parameters (except sulfur content), both the diesel fuel fractions comply with GOST 305-82: sample no. 1 - for summer; sample no. 2 - for winter brands of fuel, respectively.

After diesel fraction is hydrotreated its thermal properties shall be put in compliance with GOST 305-82 for winter fuel by the most economically effective way - use of depressor additives.

\subsection{Operational Characteristics of Vacuum Residue and Commercial Marks Of Bitumen}

Vacuum residues $\left(>350{ }^{\circ} \mathrm{C},>400{ }^{\circ} \mathrm{C}\right.$ and $\left.>440{ }^{\circ} \mathrm{C}\right)$ were examined for compliance with characteristics, established for bitumen (Silva et al., 2010; Chappat, 1994; Kemalov \& Kemalov, 2013; Ongel \& Hugener, 2014; Yan et al., 2014; Poulikakos et al., 2014; Lv et al., 2014). Due to low thermal stability of compounds contained in the natural bitumen (mainly organosulfur compounds), it is quite difficult to get residues with deep degree of distillate fractions recovery, even with the residual pressure $10 \mathrm{~mm} \mathrm{hg}$.

Natural bitumen is also an excellent raw for residual asphalt production, as it is characterized by high content of asphaltene-resin components (Lipaev, 2012; Mustafaev et al., 2013; Junaid et al., 2010; Lu et al., 2014; Zoorob et al., 2014).

Characteristics of vacuum residues in terms of compliance with commercial bitumen are given in Table 4.

According to Table 4, the studied vacuum residues are closer to the following oil bitumen marks: residue $>440^{\circ} \mathrm{C}$ - to construction bitumen of $\mathrm{BN} 50 / 50$ mark, residues $>350^{\circ} \mathrm{C}$ and $>400{ }^{\circ} \mathrm{C}$ - to viscous road bitumen of BND 60/90 and BND 40/60 marks. Norms for these bitumen marks are also given for reference in Table 4.

The undoubted advantage of these residues is low brittle temperature due to the small paraffin content in natural bitumen. The brittle point is one of the key figures of the road bitumen marks, which has a significant impact on road surface durability. In terms of this figure, the studied vacuum residues comply with GOST requirements. 
Table 4. Characteristics of vacuum residue fractions and composition and road bitumen according to standards

\begin{tabular}{llll}
\hline Characteristics of vacuum residue fractions & \multicolumn{3}{l}{} \\
\hline Indicators & $>350{ }^{\circ} \mathrm{C}$ & $>400{ }^{\circ} \mathrm{C}$ & $>440{ }^{\circ} \mathrm{C}$ \\
\hline Softening point, ${ }^{\circ} \mathrm{C}$ & 45 & 51 & 58 \\
Ductility at $25{ }^{\circ} \mathrm{C}, \mathrm{cm}$ & 47 & 40 & 35 \\
Penetration at $25{ }^{\circ} \mathrm{C}, 0,1 \mathrm{~mm}$ & Compliant to sample No. 1 & 30 \\
Adhesion with marble or sand & -23 & -19 & -17 \\
Brittle point, ${ }^{\circ} \mathrm{C}$ & 230 & 235 & 240 \\
Flashing point, ${ }^{\circ} \mathrm{C}$ & &
\end{tabular}

Construction bitumen BN 50/50 (GOST 6617-76, 1977) and viscous road bitumen of the marks of BND 60/90 and BND 40/60 (GOST 22245-90, 1991)

\begin{tabular}{|c|c|c|c|}
\hline \multirow[b]{3}{*}{ Penetration at $25^{\circ} \mathrm{C}, 0,1 \mathrm{~mm}$} & \multicolumn{3}{|c|}{ Norms for the marks } \\
\hline & BN 50/50 & BND $60 / 90$ & $\mathrm{BN} 40 / 60$ \\
\hline & $41-60$ & $61-90$ & $40-60$ \\
\hline Ductility at $25^{\circ} \mathrm{C}, \mathrm{cm}$ & no $<40$ & no $<55$ & no $<45$ \\
\hline Softening point, ${ }^{\circ} \mathrm{C}$ & $50-60$ & no $<47$ & no $<51$ \\
\hline Brittle point, ${ }^{\circ} \mathrm{C}$ & - & no $>(-15)$ & no $>(-12)$ \\
\hline Flashing point, ${ }^{\circ} \mathrm{C}$ & no $<230$ & no $<230$ & no $<230$ \\
\hline
\end{tabular}

\subsection{Possible Ways of Use of Fractions}

Modification of the studied fractions can be used to bring the values of all their parameters into full compliance with norms of the specified bitumen marks as well as with norms of other pavement and building bitumen marks.

These residues may serve the basis for preparation of various compositions, including bitumen-polymer compositions for road and civil construction (bituminous mastic and anticorrosion coatings).

In terms of bitumen-polymer composition preparation, the best figures are shown by the residue $>350{ }^{\circ} \mathrm{C}$, as positive influence of polymer compound on bitumen characteristics is in direct relationship to its lube fraction content. From this perspective, for mastic production it is feasible to use bitumen with a lower melting point. Furthermore, along with the melting point increase the bitumen becomes hard and fragile, as the asphaltene content is increased and the disperse medium becomes less flexible and frost resistant. The addition of lube fractions improves low temperature characteristics of the composition.

Quite significant sulfur content (about 3\% mass) in vacuum distillates that is so undesirable for lube fractions, is extremely favourable to preparation of bitumen-polymer compositions as in this case sulfur acts as a curing agent, which in particular improves strength of asphalt-concrete mixes based on bitumen-polymer binders.

\section{Conclusion}

Production of residual bitumen of the high-viscosity oils and natural bitumen of Tatarstan Republic (as well as any other region having raw materials with similar composition) will contribute to increase in their production volume and quality by means of compounding of residual and air-blown bitumen, as in this particular case their advantages are combined. In addition, this will contribute to solution of the problem related to introduction of water-bitumen emulsions and bitumen-polymer binders into the road construction of Tatarstan Republic.

The use of natural bitumen for production of various commercial bitumen marks and various bitumen products, makes its recovery economically feasible as its conventional recovery and transportation is noncompetitive against conventional oils.

At the same time, profitability of a pure bitumen option can be increased by means of a bitumen-fuel option, provided that the diesel fraction is brought in full compliance with the GOST for S (summer), W (winter) and A (arctic) marks of diesel fuel (GOST 305-82, 1983).

Hence, according to the foregoing results of studies of Nagornoye Deposit natural bitumen composition and characteristics, the most profitable trend of its processing is a bitumen-fuel option, which helps to obtain diesel fuels, various marks of residual bitumen and bitumen compositions for road and civil construction.

In this context, there was drawn a plan for further studies aimed at dealing with the following issues:

1. Bringing diesel fractions after hydrotreating to winter marks by means of selection of appropriate depressor additives; 
2. Use of vacuum residue for pavement and construction bitumen marks production;

3. Bitumen compositions production (mastic, paint materials) for road and civil construction;

4. Development of water-repellent agents on the basis of natural bitumen.

\section{Acknowledgements}

The work is performed according to the Russian Government Program of Competitive Growth of Kazan Federal University.

\section{References}

Altgelt, K. H. (1993). Composition and Analysis of Heavy Petroleum Fractions. Boca Raton, Florida: CRC Press. ISBN 0824789466, 9780824789466. http://dx.doi.org/10.1201/b16931

Burruss, R. C., \& Ryder, R. T. (2013). Composition of crude oil and natural gas produced from 14 wells in the Lower Silurian "Clinton" sandstone and Medina Group, northeastern Ohio and northwestern a. PennsylvaniOpen-File Report 03-409. U.S. Geological Survey, Reston, Virginia 20192. Retrieved August 20, 2014, from http://pubs.usgs.gov/of/2003/of03-409/of03-409.pdf

Chappat, M. (1994). Some applications of emulsions. Colloids and Surfaces A: Physicochemical and Engineering Aspects, 91(C), 57-77. http://dx.doi.org/10.1016/0927-7757(94)02976-8.

Etherington, J. R., \& McDonald, I. R. (2005). Is bitumen a petroleum reserve? Hydrocarbon Development - A Global Challenge: Proceedings of SPE Hydrocarbon Economics and Evaluation Symposium (code 65980. Article number SPE 90242, pp. 15-21), Apr. 3-5, Dallas, TX; USA. http://dx.doi.org/10.2118/90242-MS

GOST 11501-78. Petroleum bitumens. Method for determination of depth of penetrometer needle penetration (1980, January 01). Retrieved September 10, 2014 from http://www.tdtoap.ru/pubs/19/

GOST 11505-75. Petroleum bitumen. Method for determination of ductility (1977, January 01). Retrieved September 10, 2014, from http://www.ohranatruda.ru/ot_biblio/normativ/data_normativ/3/3872/index.php

GOST 11507-78. Petroleum bitumen. Method for determination of brittle point (1980, January 01). Retrieved September 10, 2014, from http://www.ohranatruda.ru/ot_biblio/normativ/data_normativ/3/3874/index.php.

GOST 11508-74. Petroleum bitumen. Methods of determination of bitumen adhesion to marble and sand (1975, January 01). Retrieved September 10, 2014, from http://ohranatruda.ru/ot_biblio/normativ/data normativ/6/6153/

GOST 11851-85. Petroleum. Method of paraffin determination. (1986, January 01). In standards library. Retrieved September 10, 2014, from http://files.stroyinf.ru/Data1/17/17347/index.htm

GOST 1437-75. Dark petroleum products. Accelerated method for determination of sulphur. (1977, January 01). In standards library. Retrieved September 10, 2014, from http://vsegost.com/Catalog/21/2101.shtml

GOST 19121-73. Petroleum products. Determination of sulphur content by lamp method. (1974, July 01). In standards library. Retrieved September 10, 2014, from http://www.znaytovar.ru/gost/2/GOST_1912173_ Nefteprodukty_Met.html.

GOST 20287-91. Petroleum products. Methods of test for flow point and pour point (1992, January 01). In standards library. Retrieved September 10, 2014, from http://www.gosthelp.ru/text/GOST2028791 NefteproduktyM.html

GOST 2070-82. Light petroleum products. Methods for determination of iodine numbers and content of unsaturated hydrocarbons. (1983, July 01). In standards library. Retrieved September 10, 2014, from http://www.gosthelp.ru/text/GOST207082Nefteproduktysv.html

GOST 22245-90. Viscous petroleum road bitumens. Specifications (1991, January 1). In standards library. Retrieved September 10, 2014, from http://vsegost.com/Catalog/28/28407.shtml

GOST 305-82. Diesel fuel. Specifications (1983, January 1). In standards library. Retrieved September 10, 2014, from http://vsegost.com/Catalog/21/21888.shtml

GOST 3122-67. Diesel fuel. Method for determination of cetane index (1968, January 01). In standards library. Retrieved September 10, 2014, from http://www.gosthelp.ru/text/GOST312267Toplivadizelnye.html

GOST 4333-87. Methods for determining the flash point and ignition point in an open crucible (1988, July 01). Retrieved September 10, 2014 from http://www.vashdom.ru/gost/4333-87

GOST 5066-91 (ISO 3013-74). Motor fuels. Methods for determination of cloud, chilling and freezing points 
(1993, January 01). In standards library. Retrieved September 10, 2014, from http://www.gosthelp.ru/text/ GOST506691Toplivamotornye.html

GOST 5985-79. Petroleum products. Method for determination of acidity and acid number (1980, January 01). In standards library. Retrieved September 10, 2014, from http://www.vashdom.ru/gost/5985-79/.

GOST 6617-76. Petroleum construction, bitumens. Specifications (1977, July 01). In standards library. Retrieved September 10, 2014, from http://vsegost.com/Catalog/81/8169.shtml

GOST 8226-82. Fuel for the engines. The research method for the determination of octane number (1982, July 01). In standards library. Retrieved September 10, 2014, from http://www.gosthelp.ru/gost/gost13432.html

GOST 8489-85. Motor fuel. Method for determination of existent gums (Budaroys) (1986, July 01). In standards library. Retrieved September 10, 2014, from http://www.vashdom.ru/gost/8489-85/.

GOST R 51858-2002. Crude petroleum. General specifications (2002, July 01). In standards library. Retrieved September 10, 2014, from http://www.standartov.ru/norma_doc/10/10031/index.htm

Junaid, A. S. M., Wang, W., Street, C., Rahman, M., McCaffrey, W., \& Kuznicki, S. (2010). Upgrading of Athabasca oilsands bitumen by low temperature natural zeolite cracking. The Proceedings of 2010 AIChE Annual Meeting, 10AIChE; Nov. 7-12, Salt Lake City, UT; USA, 1 p. ISBN: 978-081691065-6.

Kemalov, A. F., \& Kemalov, R. A. (2013). Development of the Technology of Macromolecular Structuring of Naphtha Crude Residues During Their Oxidation to Produce Bitumen Insulation Materials. World Applied Sciences Journal (Special Issue on Techniques and Technologies), 22, 91-95. http://dx.doi.org/10.5829/ idosi.wasj.2013.22.tt.22146.

Kemalov, A. F., \& Kemalov, R. A. (2013). Practical Aspects of Development of Universal Emulsifiers for Aqueous Bituminous Emulsions. World Applied Sciences Journal, 23(6), 858-862. http://dx.doi.org/ 10.5829/idosi.wasj.2013.23.06.13103

Khisamov, R. S., Gatiyatulin, N. S., \& Shargorodsky, I. E. (2006). The preparation for the development of natural bitumen fields in the Republic of Tatarstan. Neftyanoe Khozyaistvo - Oil Industry, 2, 42-46.

Kraus, R. S. (2011). Petroleum Refining Process, Oil and Natural Gas. Encyclopedia of Occupational Health and Safety (p. 397). Geneva, Switzerland: International Labor Organization.

Liao, M. -C., Chen, J. -S., Airey, G. D., \& Wang, S. -J. (2014). Rheological behavior of bitumen mixed with Trinidad lake asphalt. Construction and Building Materials, 66, 361-367. http://dx.doi.org/10.1016/j. conbuildmat.2014.05.068.

Lipaev, A. (2012). Criteria for selection of methods for high viscous heavy crude oil and natural bitumen field development. Modern Management of Mine Producing, Geology and Environmental Protection: Proceedings of the 12th International Multidisciplinary Scientific GeoConference and EXPO, SGEM 2012 (vol. 1, pp. 511-514), June 17-23, SGEM 2012, Varna; Bulgaria. http://dx.doi.org/10.5593/SGEM2012/ S03.V1014

Long, J., Xu, Z. and Masliyah, J.H. (2006). Role of illite-illite interactions in oil sands processing. Colloids and Surfaces A: Physicochemical and Engineering Aspects, 281(1-3), 202-214. http://dx.doi.org/10.1016/j. colsurfa.2006.02.059.

Lu, X., Said, S., Carlsson, H., Soenen, H., Heyrman, S., \& Redelius, P. (2014). Evaluation of test sections with Polymer Modified Bitumens. Asphalt Pavements: Proceedings of the International Conference on Asphalt Pavements, ISAP 2014 (Vol. 1, pp. 287-296. Code 106202). June 1-5, Raleigh, NC, USA.

Lv, D. W., He, J., \& Sun, X. L. (2014). Indoor study on road performance of macromolecule polymer bitumen waterproof and cohesive layer (PCMA). Advanced Materials Research: Proceedings of 2014 International Conference on Frontiers of Advanced Materials and Engineering Technology, FAMET 2014 (Vol. 912-914, pp. 172-177. Code 105247). March 28-29. http://dx.doi.org/10.4028/www.scientific.net/AMR.912-914.172.

Mustafaev, I. I., Jabbarova, L. Yu, Nabizade, Z. O., Ibadov, N. E., \& Akhmedbekova, S. F. (2013). A study of radiation-chemical conversion of synthetic oil derived from oil-bitumen rock. High Energy Chemistry, 47(6), 301-307. http://dx.doi.org/10.1134/S0018143913060064.

Mykhailova, L., Fischer, T., \& Iurchenko, V. (2013). Distribution and Fractional Composition of Petroleum Hydrocarbons in Roadside Soils. Applied and Environmental Soil Science. http://dx.doi.org/10.1155/2013/ 938703. 
Ongel, A., \& Hugener, M. (2014). Aging of bituminous mixes for rap simulation. Construction and Building Materials, 68, 49-54. http://dx.doi.org/10.1016/j.conbuildmat.2014.06.030.

Pavel, S. K., \& Silverman, M. A. (2010). Heavy oil upgrading with HTL technology. The Proceedings of the 2010 AIChE Spring Meeting and 6th Global Congress on Process Safety, 10AIChE; March 21-25, San Antonio, TX; USA, 1 p. ISBN: 978-081691064-9.

Poulikakos, L. D., dos Santos, S., Bueno, M., Kuentzel, S., Hugener, M., \& Partl, M. N. (2014). Influence of short and long term aging on chemical, microstructural and macro-mechanical properties of recycled asphalt mixtures. Construction and Building Materials, 51, 414-423. http://dx.doi.org/10.1016/j. conbuildmat.2013.11.004.

Poveda, J. C., \& Molina, D. R. (2012). Average molecular parameters of heavy crude oils and their fractions using NMR spectroscopy. Journal of Petroleum Science and Engineering, 84-85, 1-7. http://dx.doi.org/ 10.1016/j.petrol.2012.01.005.

Prado, G. H. C., \& De Klerk, A. (2014). Halogenation of oilsands bitumen, maltenes, and asphaltenes. Energy and Fuels, 28(7), 4458-4468. http://dx.doi.org/10.1021/ef500712r.

Riazi, M. R., \& Daubert, T. E. (1980). Prediction of the Composition of Petroleum Fractions. Industrial and Engineering Chemistry Process Design and Development, 19(2), 289-294. http://dx.doi.org/10.1021/ i260074a016.

Salama, A. I. A. (2005). On the application of heat integration in oil sands processing. The Proceedings of the 14th International Symposium on Mine Planning and Equipment Selection, MPES 2005 and the 5th International Conference on Computer Applications in the Minerals Industries, CAMI 2005 (pp. 1125-1141), Oct. 31-Nov. 3, Banff, AB; Canada, Code 102040.

Silva, H. M. R. D., Oliveira, J. R. M., Peralta, J., Zoorob, S. E. (2010). Optimization of warm mix asphalts using different blends of binders and synthetic paraffin wax contents. Construction and Building Materials, 24(9), 1621-1631. http://dx.doi.org/10.1016/j.conbuildmat.2010.02.030.

Speight, J. G. (2014). The Chemistry and Technology of Petroleum (5th ed.). Boca Raton, Florida: CRC Press.

Telyashev, E. (2008). Promising technologies of heavy oils and natural bitumens processing. A World in Transition: Delivering Energy for Sustainable Growth: Proceedings of Energy Institute - 19th World Petroleum Congress (Vol. 2, pp. 659-660), 2008, June 29-July 3, Madrid; Spain. ISBN: 978-161567683-5.

Yan, X., C. Liang, C., Ai, T., \& An, S. (2014). Study on the visco-plastic model of the interfacial shear between bitumen and stone. Tumu Gongcheng Xuebao/China Civil Engineering Journal, 47(2), 136-144.

Zoorob, S. E., Kamaruddin, I. B., \& Madzlan, B. N. (2014). The use of bitumen linear viscoelastic properties to assess rutting sensitivity. Applied Mechanics and Materials, 567, 755-762. http://dx.doi.org/10.4028/www.scientific.net/AMM.567.755.

\section{Copyrights}

Copyright for this article is retained by the author(s), with first publication rights granted to the journal.

This is an open-access article distributed under the terms and conditions of the Creative Commons Attribution license (http://creativecommons.org/licenses/by/3.0/). 